\title{
The Prevelance of Low Back Pain and Risk Factors Among Nurses Working in a University Hospital: A Cross Sectional Study
}

\author{
Bir Üniversite Hastanesinde Çalışan Hemşirelerde Bel Ağrısı \\ Görülme Sıklığı ve Risk Faktörleri: Kesitsel Çalışma
}

(1) Özlem Akçakaya Koğa ${ }^{1}$, (1) Pınar Özdemir Deniz ${ }^{2}$, (1) Filiz Abacıgil², (1) Erdal Beşer ${ }^{2}$

${ }^{1}$ Aydın Adnan Menderes University Faculty of Health Sciences, Department of Public Health Nursing, Aydın, Turkey

${ }^{2}$ Aydın Adnan Menderes University Faculty of Medicine, Department of Public Health, Aydın, Turkey

Keywords

Low back pain, nurses, musculoskeletal diseases, occupational health, occupational safety

Anahtar Kelimeler

Bel ağrısı, hemşireler, kas-iskelet hastalıkları, iş sağlığı, iş güvenliği

Received/Geliş Tarihi : 08.09.2017

Accepted/Kabul Tarihi : 25.04.2018

doi:10.4274/meandros.galenos.2018.50570

Address for Correspondence/Yazışma Adresi: Pınar Özdemir Deniz MD,

Aydın Adnan Menderes University Faculty of Medicine, Department of Public Health, Aydın, Turkey

Phone : +90 5079901286

E-mail : pinnarozdemir@gmail.com

ORCID ID: orcid.org/0000-0001-8813-6970

CCMeandros Medical and Dental Journal, Published by Galenos Publishing House.

This is article distributed under the terms of the Creative Commons Attribution NonCommercial 4.0 International Licence (CC BY-NC 4.0).

\begin{abstract}
Objective: Aim of the study is to determine the incidence of low back pain (LBP) and risk factors in nurses working in a university hospital.

Materials and Methods: This cross-sectional study was conducted in 253 nurses working in a university hospital. The data were collected by questionnaire. The questionnaire form has two parts. First part includes demographics, work related risk factors, presence/severity of LBP, factors that cause LBP and training in using low back at work. Second part includes Oswestry Disability index (ODI). Descriptive statistics are presented as number, percentage, median (minimum-maximum). Chisquare test, binominal logistic regression analysis was used for analysis.

Results: The prevalence of ongoing LBP is 21.1\%. According to the ODI score, mild disability was found in $44.9 \%$. The percentage of nurses who have been trained in using back exercises at work is $32.8 \%$. The prevalence of LBP was higher among the elderly, married ones, nurses with trauma stories, pregnancy stories, daytime workers and nurses who worked for more than 10 years $(p<0.001)$. Trauma story and working more than 10 years in profession increase the risk $(p<0.05)$.

Conclusion: Health workers, especially nurses, should be educated about awareness of risk factors at work, using of low back at work and trainings on simple exercises that can be done at work; the working conditions of nurses should be revised in line with the risk factors; ergonomic working environment should be provided. With these approaches, health workers' life quality can be increased and the loss of work power caused by pain will be minimized and financial losses will be prevented.
\end{abstract}

Öz

Amaç: Bu çalışmada bir üniversite hastanesinde çalışan hemşirelerde bel ağrısı görülme sıklığı ve risk faktörlerinin belirlenmesi amaçlanmıştır.

Gereç ve Yöntemler: Çalışma kesitsel tipte olup, bir üniversite hastanesinde çalışan 253 hemşirede gerçekleştirilmiş̧ir. Veriler anket ile toplanmıştır. Anketin ilk bölümünde sosyo-demografik özellikler, bel ağrısı risk faktörleri, mevcut bel ağrısı durumu/şiddeti ve bel ağrısını ortaya çıkaran etmenler, iş yaşamında bel mekaniğini kullanma konusunda eğitim alma durumu sorgulanmıştır. İkinci 
bölümde ise Oswestry Bel Ağrısı Ölçeği (OBAÖ) kullanılmıştır. Analitik değerlendirmede "ki-kare testi, binominal lojistik regresyon analizi" kullanılmıştır.

Bulgular: Halen devam eden bel ağrısı prevelansı \%21,1'dir. OBAÖ'ye göre \%44,9'unda hafif engellilik saptanmıştır. İş yaşamında bel mekaniğini kullanma konusunda eğitim alan \%32,8'dir. İleri yaşta olanlarda, evlilerde, gebelik öyküsü, travma öyküsü olanlarda, gündüz çalışanlarda, meslekte çalışma süresi 10 yıldan fazla olanlarda bel ağrısı görülme sıklığının fazla olduğu saptanmıştır ( $p<0,001)$. Travma öyküsü ve meslekte 10 yıldan fazla çalışmanın riski artırdığı izlenmiştir $(p<0,05)$.

Sonuç: Özellikle hemşireler başta olmak üzere sağlık çalışanlarına iş yerlerinde bel bölgesi problemine neden olan risk faktörleri ve iş yaşamında bel mekaniğini kullanmayla ilgili farkındalık eğitimleri düzenlenmeli, iş yerinde yapılabilecek basit egzersizler hakkında eğitimler verilmeli, kişilerin çalışma koşulları risk faktörleri doğrultusunda revize edilmeli, ergonomik çalışma ortamları sağlanmalıdır. Bu yaklaşımlarla sağlık personelinin yaşam kalitesini artırılabileceği gibi, ağrının yol açtığı iş gücü kaybı en aza indirilecek, mali anlamda kayıplar önlenecektir.

\section{Introduction}

Musculoskeletal system disorders including low back pain are among the most common chronic diseases. According to studies, $70-85 \%$ of people experience low back pain at some point in their lives (1). Low back pain was among the top four leading causes of disability in the 2010 global burden of disease study (2). According to the studies conducted in Turkey, the prevalence of low back problems (low back pain, hernia etc.) is $33 \%$ in all population (3) and 44-79\% in nurses (4). According to the 2015 Health Statistics Yearbook, low back problems take the top position within the five disorders that people of both sexes experience in Turkey (3).

According to the data obtained from the Turkish Statistics Institute, musculoskeletal disorders constitute $24.9 \%$ of occupational health problems (5). Studies from Europe declaired that $40 \%$ of the amount of compensation received by workers is due to musculoskeletal system disorders and related medical expenses constitute $1.6 \%$ of the gross national products. Cost analyses of low back pain carried out in developed countries, indicated a high level of financial burden of low back pain (6-9). The study of Icagasioglu et al. (9) which was the first study about the cost analysis of low back pain in Turkey showed that the total direct cost of chronic low back pain was 714.734 TL (Turkish liras) and 1.080 TL per person in 2014. In the same study, total indirect cost of chronic low back pain was 3.648.057 and 5.511 TL per person (9). In the above mentioned study, the financial burden caused by absenteeism was not included in the calculation; only disease related costs were calculated. If loss of man-hours were included in the calculation, the cost would increase significantly.

Occupational musculoskeletal system disorders are the most common occupational diseases among healthcare professionals (10). Therefore, many studies on this subject have been conducted in healthcare professionals. Nurses, in their daily work are exposed to different risk factors related with low back pain as a result of their nature of work such as patient care, positioning patients, patient transfer, standing for long hours etc. The prevalence of low back pain among nurses was found to be $62.9 \%$ in a study conducted in 2176 nurses in Germany and this percentage was $72 \%$ in the study of Shieh S.H. et al. (11) and $84 \%$ in the study of Arasan F. et al. (12). A study found that $11 \%$ of nurses leave their work due to low back pain (13).

Due to long term negative effects on health and associated financial burden of low back pain, it is important to develop an intervention program to identify the extent and causes of low back problems in nurses who are exposed to occupational risks and include ergonomic arrangements to eliminate such problems. Therefore the aim of this study was to determine the frequency of low back pain in nurses working in Aydın Adnan Menderes University Research and Training Hospital and associated risk factors.

\section{Materials and Method}

This is a cross sectional study. The population of the study was the nurses working in the inpatient units, intensive care, dialysis, outpatient clinics in Aydın Adnan Menderes University Research and Training Hospital. The study sample size is 384 , with alpha $5 \%$, power $80 \%$, sample error 0.03 and prevalence $50 \%$. Out of targeted 384 people we managed to reach to $65.8 \%(253)$ due to various reasons such as maternity leave, annual leave, and rejection to participate to the study. Non-interventional Clinical Research Ethics Committee of the University approved the study which protocol number 2016/809. Participation in the study is based on volunteerism. 
Participants completed the questionnaire between March 2016 - May 2016. Participants completed the assessment questionnaires in their free time. The questionnaire consists of two sections with a total of 27 items. Socio-demographics questions (age, sex, weight, height, education, marital status), questions on low back pain risk factors (pregnancy, economic status, department in the hospital, how many years working as a nurse, working time, smoking habits, familial tendency), low back pain experience, ongoing low back pain/severity and factors causing low back pain, treatment and therapy for low back pain, and education on using back supports during work were included in the first section. Oswestry Disability index (ODI) $(14,15)$ was used in the second section of the questionnaire. Low back pain was expressed as persistent, ongoing low back pain (whole day pain for minimum two weeks, which requires treatment).

The ODI was developed to assess functionality; the validity and reliability study of the Turkish version was done by Yakut et al. (16). The scale consists of 10 sections that question pain severity, personal care, weight lifting, walking, sitting, standing times, sleep, sex life, social life, travelling and each section has 6 questions. Each section has a separate scoring on a scale of 5 points. The scale is evaluated based on the total score and minimum score is 0 whereas maximum score is 50 . Zero - four points are no disability, 5-15 points are mild disability; $15-24$ points are moderate disability; 25-25 points are severe disability and 35-50 points are full disability.

Statistical evaluation of data was done by the SPSS program. Descriptive statistics were presented as numbers, percentage and median (minimummaximum) values. Kolmogorov-Smirnov test was used as a goodness of fit test for normal distribution; and the chi-square test was used for analytic evaluations; and binary logistic regression analysis was used for independent risk factors with a significant relationship with the prevalence of low back pain and BackwardWald method was used for modelling. The results of logistic regression analysis were showed as relative risk [odds ratio (OR)] and 95\% confidence interval (CI). Hosmer-Lemeshow test for goodness of fit of a logistic regression model was used. Type 1 error level was 0.05 .

\section{Results}

From total of 253 nurses, $89.3 \%$ of them was female $(n=226)$ and the median age of all nurses was 26 (18-54). Median height of the participants was 165 $\mathrm{cm}$ (150-196), median weight was $63 \mathrm{~kg}$ (40 kg-111 $\mathrm{kg})$; median body mass index was $23.0 \mathrm{~kg} / \mathrm{m}^{2}(15.6 \mathrm{~kg} /$ $\left.\mathrm{m}^{2}-39.1 \mathrm{~kg} / \mathrm{m}^{2}\right) .53 .8 \%$ of the participants were single and $58.9 \%$ had a bachelor's degree. $59.7 \%$ of the nurses reported that they had a "balanced budget". $31.6 \%$ of the nurses participated in the study $(n=80)$ had a pregnancy history and the median number of pregnancies was 2 (0-5). 35.6\% of the participants were smokers.

Among all of the participants $66.3 \%$ of them were nurses who working in the inpatient wards, $19.0 \%$ were working in the intensive care unit, $8.7 \%$ were working in the outpatient clinics and $6.0 \%$ were working in the operating room. The median employment time of the participants was 46 months ( 3 months - 389 months); median weekly working time was 45 hours ( 36 hours 56 hours) and $64.5 \%$ of the participants were working in the night shift.

Regarding the general health stats of the participants $13.4 \%$ of them had chronic diseases which required continuous use of medications and the majority of such diseases were endocrine disorders. $15.5 \%$ of the nurses reported that they exercised for minimum 45 minutes three times a week. $32.8 \%$ of the nurses $(n=82)$ reported that they received training on using low back supports during work.

Lifetime prevelance of severe low back pain problem was $28.2 \%(n=71)$ and ongoing low back pain problem was $21.1 \%(n=52)$. The median duration for ongoing low back pain was 12 months (1 month 240 months). $62.8 \%$ of the nurses reported low back history in their families.

The distribution of factors affecting low back pain in nurses is shown in Table 1.

Univariate analyses showed that age, marital status, low back pain history in the family, pregnancy history, past traumas, working conditions and employment time influenced the frequency of low back pain. According to this, as age and employment time increases, the prevalence of low back pain also increases. Low back pain was observed more frequently in married nurses, nurses who had low back pain history in their families, trauma history and in those who worked only in day shifts (Table 1). 


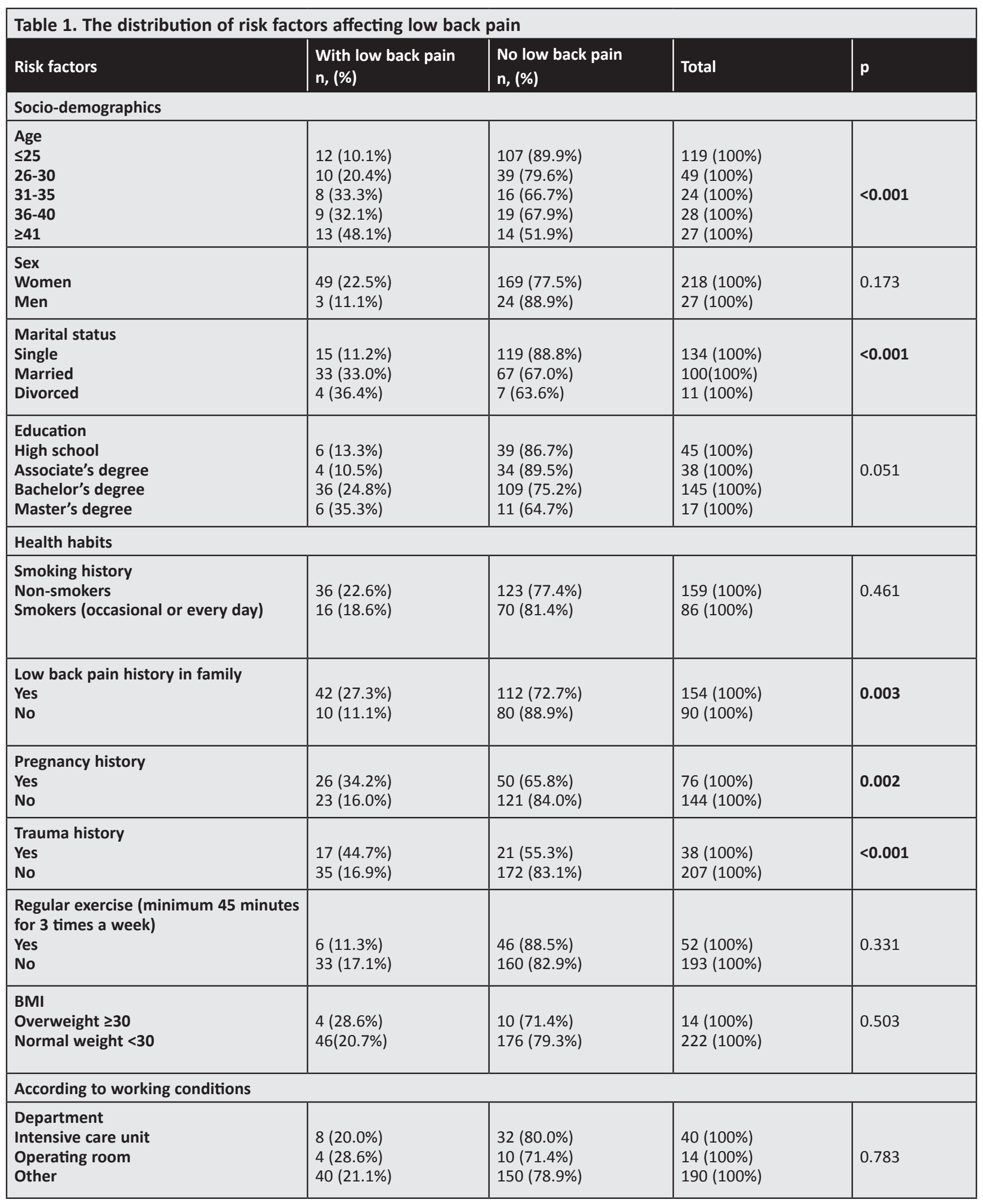




\section{Table 1 contiuned}

\begin{tabular}{|c|c|c|c|c|}
\hline $\begin{array}{l}\text { Work shifts } \\
\text { Day } \\
\text { Night } \\
\text { Day + night }\end{array}$ & $\begin{array}{l}25(32.1 \%) \\
2(22.2 \%) \\
25(15.8 \%)\end{array}$ & $\begin{array}{l}53(67.9 \%) \\
7(77.8 \%) \\
133(84.2 \%)\end{array}$ & $\begin{array}{l}78(100 \%) \\
9(100 \%) \\
158(100 \%)\end{array}$ & 0.016 \\
\hline $\begin{array}{l}\text { Daily working time } \\
\leq 8 \text { hours } \\
8-12 \text { hours } \\
\geq 12 \text { hours }\end{array}$ & $\begin{array}{l}31(25.2 \%) \\
4(19.0 \%) \\
17(16.5 \%)\end{array}$ & $\begin{array}{l}92(74.8 \%) \\
17(81.0 \%) \\
86(83.5 \%)\end{array}$ & $\begin{array}{l}123(100 \%) \\
21(100 \%) \\
103(100 \%)\end{array}$ & 0.272 \\
\hline $\begin{array}{l}\text { Employment time } \\
\leq 1 \text { year } \\
1-5 \text { years } \\
6-10 \text { years } \\
\geq 10 \text { years }\end{array}$ & $\begin{array}{l}3(15.8 \%) \\
14(11.5 \%) \\
13(27.1 \%) \\
22(37.9 \%)\end{array}$ & $\begin{array}{l}16(84.2 \%) \\
108(88.5 \%) \\
35(72.9 \%) \\
36(62.1 \%)\end{array}$ & $\begin{array}{l}19(100 \%) \\
122(100 \%) \\
48(100 \%) \\
58(100 \%)\end{array}$ & $<0.001$ \\
\hline $\begin{array}{l}\text { Financial status } \\
\text { Income is less than expenses } \\
\text { Balanced budget or } \\
\text { income is more than expenses }\end{array}$ & $\begin{array}{l}16(20.0 \%) \\
36(21.8 \%)\end{array}$ & $\begin{array}{l}64(80.0 \%) \\
129(78.2 \%)\end{array}$ & $\begin{array}{l}80(100 \%) \\
165(100 \%)\end{array}$ & 0.744 \\
\hline
\end{tabular}

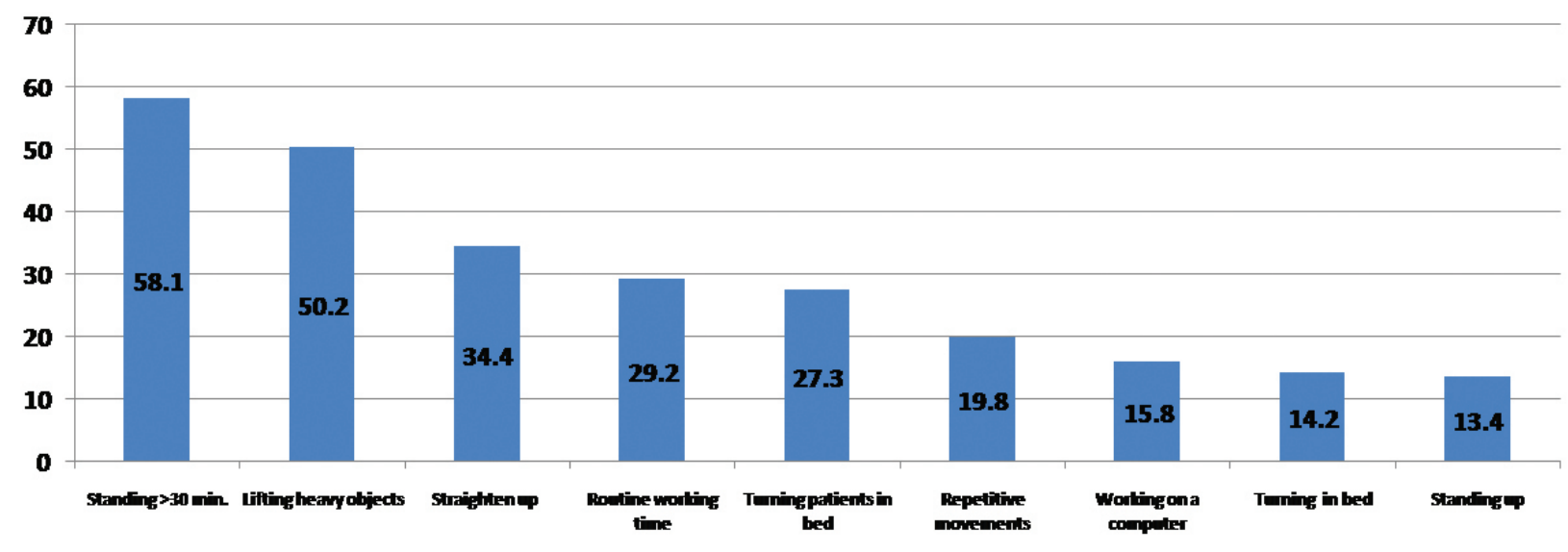

Graphic 1. Contributing factors for low pain

When contributing factors for low back pain were investigated, nurses reported that they had low back pain the most when they stand longer than $30 \mathrm{~min}$. (58.1\%), when they lift heavy objects/people (50.2\%), when they straighten up after bending dow (34.4\%) (Graphic 1).

Logistic regression analysis was done to determine the possible risk factors that increase low back pain frequency. In this analysis, presence of ongoing low back pain problem was taken as dichotomous variable whereas age, marital status, low back pain history in the family, pregnancy history, past traumas, working conditions and employment time were taken as independent variables. In the analysis, trauma history increased low back pain frequency by 2.66 times (OR: 2.66, 1.14-6.23) and employment time longer than ten years by 2.99 times (OR: 2.99, 1.11-6.13). Table 2 shows last step outputs of logistic regression analysis.

The median score in ODI was $6(0-27)$. When the distribution of nurses according to the ODI was examined, $44.9 \%$ had a mild disability; there was only one person with a severe disability according to the scale (Table 3). 


\begin{tabular}{|c|c|c|}
\hline & $\begin{array}{l}\text { OR }(95 \% \mathrm{Cl}) \\
(n=235)\end{array}$ & p \\
\hline $\begin{array}{l}\text { Trauma history } \\
\text { Yes } \\
\text { No* }\end{array}$ & $2.66(1.14-6.23)$ & 0.023 \\
\hline $\begin{array}{l}\text { Low back pain history in family } \\
\text { Yes } \\
\text { No* }\end{array}$ & $2.08(0.95-4.55)$ & 0.066 \\
\hline $\begin{array}{c}\text { Employment time } \\
\leq 10 \text { years* } \\
>10 \text { years }\end{array}$ & $2.99(1.50-5.98)$ & 0.002 \\
\hline \multicolumn{3}{|c|}{$\begin{array}{l}\mathrm{CI} \text { : Confident interval, OR: Odds ratio } \\
\text { *: Reference group } \\
\text { Hosmer-Lemeshow test for goodness of fit test } \chi 2=0.966, p=0.915\end{array}$} \\
\hline
\end{tabular}

\begin{tabular}{|c|c|c|}
\hline Scale scores & Number (n) & Percentage (\%) \\
\hline No disability (0-4) & 71 & 45.5 \\
\hline Mild (5-14) & 70 & 44.9 \\
\hline Moderate (15-24) & 14 & 9.0 \\
\hline Severe (25-34) & 1 & 0.6 \\
\hline Full (35-50) & 0 & 0.0 \\
\hline Total & 152 & 100 \\
\hline
\end{tabular}

\section{Discussion}

There are many studies on the prevalence of low back pain in nurses both in Turkey and in other countries in the world. The prevalence of low back pain changes between $44 \%$ to $79 \%$ in the studies published in Turkey (4). In this study which prevalence and contributing factors of low back pain in nurses were investigated, ongoing low back pain was found in $21.1 \%$ of the nurses; This percentage is lower than the findings of similar studies conducted in Turkey. In the studies on the prevalence of low back pain in nurses worldwide, the prevalence was $75 \%$ in Greece (17), 73-76\% in Germany (18), 64\% in Switzerland (19), $29 \%$ in the USA (20). The reason for this could be that in this study only ongoing low back pain complaints were asked instead of any experience of low back pain during whole life period. Although the nurses in our study group was younger and had shorter employment time, the fact that one out of five nurses had this problem indicates that this is not a problem that can be ignored.
Low back pain which is the most common occupational disease has a high prevalence among nurses especially due to working conditions. In the study of Solak Kabataş et al (21), in which they investigated the prevalence of low back pain in healthcare professionals, nurses and midwifes had higher ODI scores. Standing for extended periods of time, short breaks, physically poor work conditions, lack of sleep during night shifts were among the contributing factors of low back pain (22). The study suggested that as a result of their activities such as positioning and lifting patients during patient care they strained and injured their low back muscles and thus had low back problems (23). In this study, contributing factors to low back pain as reported by the participants were standing for extended periods of time, lifting heavy items, moving and positioning patients in bed. These types of movements are physically challenging for people; if musculoskeletal system is not relaxed with simple exercises and sufficient amount of breaks, this can cause low back pain and associated health problems.

When the prevalence of low back pain in nurses according to the departments they work was examined, although no statistical significance was found, there were some studies in the literature with statistical significance $(12,24)$. In the study of Çil Akıncı et al. (24) the prevalence of low back pain in nurses working in the emergency department, operating rooms and intensive care units was higher than those working in other departments $(25,26)$. In the departments such as intensive care units, operating rooms, emergency departments where some activities of the staff may challenge them physically, low back problems are more likely to be seen. The reason why there was no difference between departments in our study could be that the participants were young and had a short employment time. All members of the staff and especially nurses working in these departments should receive information and training on ergonomics approach.

Work shifts of nurses were also a contributing factor for low back pain in our study. The prevalence of low back pain in nurses working in day shift was higher. The reason for this could be that hospital work load is more during the day and therefore nurses have to stand for longer times during the day shift. 
In our study it was observed that as age and employment time increase, the prevalence of low back pain also increases. Those who have been employed for over ten years were found to have more low back pain. Although there are studies in Turkey and in other countries with contrary findings $(27,28)$, there are also studies that support this finding $(11,12,24,29)$.

It is possible to say that one of the most important contributing factors for low back pain is personal factors. Age is an important risk factor and in many studies it was observed that low back pain increased significantly after the third decade $(12,30,31)$. In our study, age related findings support the above. The study of Cımbız et al. (32), found that an increase of one unit in age increased the low back pain occurrence risk by $3.2 \%$.

Several studies found that the gender of the patient had no statistically significant effect on the prevalence of low back pain $(27,28)$; and the findings of our study also support this. However, there are studies in the literature which suggest that the prevalence of low back pain is higher in women than in men $(21,33)$. According to the 2015 Healthcare Statistics Yearbook, the prevalence of low back problems was higher in women than men with $39.3 \%$ of women having low back problems (3). The reason why low back pain prevalence is higher in women is that hormonal factors, pregnancy define pain symptoms more in the literature $(33,34)$. Since this study included nurses, the study group consisted mostly of women. Therefore this can be the reason why there is no significant difference between genders.

The effect of marital status on the prevalence of low back pain has been investigated in many studies but no clear opinion has been reached. There are studies which claim that marital status has no effect on the prevalence of low back pain $(11,21,27,28)$, but there are also studies which demonstrate the opposite just like our study $(12,24)$.

In our study, the percentage of pregnancy history in nurses with low back pain was high and statistically significant. During pregnancy, pre and postdelivery the prevalence of low back pain caused by hormonal and mechanic effects on the low back and pelvis area increases (35). In the literature, there are studies which found a significant relationship between pregnancy and the prevalence of low back pain $(36,37)$; as well as studies with the opposite finding $(12,27)$.
The low back area is the area which is most affected area of the musculoskeletal system by mechanical stress, functional tension, occupational and sports trauma (38). In the study of Karamehmetoğlu et al. (39) which examined the relationship between trauma and low back pain, $27.4 \%$ of the reasons that induce low back pain was trauma and heavy lifting, twisting and falls were the main reasons to induce traumatic low back pain. Trauma history which was significantly related with the prevalence of low back pain in our study was asked in a way to determine whether the participants have had any trauma but the trauma details were not asked. This is one of the limitations of our study.

In our study, people who had low back pain history in their family had a high prevalence of low back pain; the findings of the study of Altmel (27) also support our findings. Especially family history of low back pain caused by rheumatoid arthritis is a major risk factor (40). In addition to this, incorrect movement patterns learned within the family can cause low back pain.

\section{Conclusion}

Low back problems which are the common reason to consult to a physician are also among the top occupational diseases and that's why it has been widely researched both in Turkey and in other countries. Risk factors which were found to be significant in the univariate analyses were analysed with the multivariate modeling method. According to multivariate analysis results, ongoing low back pain was significantly affected by trauma history and employment time of longer than ten years.

Healthcare professionals, especially nurses, should be educated about awareness of risk factors at work, using of low back at work and trainings on simple exercises that can be done at work; the working conditions of nurses should be revised in line with the risk factors; ergonomic working environment should be provided. According to the "occupational health and safety" practices, healthcare professionals with a trauma history or who has been working longer than 10 years can be transferred to more suitable departments and to positions with less active work. With these approaches, the life quality of healthcare professionals can be increased and absenteeism and presenteeism can be reduced and thus financial losses can be prevented. 
One of the strengths of the study is high low back pain prevalence was found despite the study done in a hospital with very young nurse population. It can be predicted that the problem will be higher in other health institutions with elderly healthcare professionals, especially for nurses. In addition; it is thought that our research will contribute to health and safety related practices in the hospital.

\section{Ethics}

Ethics Committee Approval: The study were approved by the Aydın Adnan Menderes University of Local Ethics Committee (protocol number: 2016/809).

Informed Consent: Consent form was filled out by all participants.

Peer-review: Externally and internally peerreviewed.

\section{Authorship Contributions}

Surgical and Medical Practices: Ö.A.K., Concept: Ö.A.K., F.A., P.Ö.D, E.B., Design: Ö.A.K., F.A., Data Collection or Processing: Ö.A.K., Analysis or Interpretation: F.A, P.Ö.D., Literature Search: P.Ö.D., Writing: P.Ö.D, F.A

Conflict of Interest: No conflict of interest was declared by the authors.

Financial Disclosure: The authors declared that this study received no financial support.

\section{References}

1. Andersson, Gunnar BJ. "Epidemiological Features Of Chronic Low-Back Pain." Lancet 1999; 354: 581-5.

2. Vos T, Flaxman AD, Naghavi M, Lozano R, Michaud C, Ezzati M, et al. Years Lived With Disability (Ylds) For 1160 Sequelae Of 289 Diseases And Injuries 1990-2010: A Systematic Analysis For The Global Burden Of Disease Study 2010. Lancet 2012; 380: 216396.

3. Sağlık İstatistikleri Yıllığı 2015. Sağlık Bakanlığı, Sağlık Araştirmaları Genel Müdürlüğü; 2015.

4. Oksuz E. Prevalence, Risk Factors And Preference-Based Health States Of, 2006;31:968-72. Low Back Pain in A T Population. S. Pubmed Result.Pdf.

5. TÜiK. İş Kazaları Ve İşe Bağlı Sağık Problemleri Araştırma Sonuçları 2013. 2014: 4-14.

6. Hong J, Reed C, Novick D, Happich M. Costs Associated With Treatment Of Chronic Low Back Pain. Spine (Phila Pa 1976) 2012; 38: 1.

7. United States Bone And Joint Iniciative: The Burden of Musculoskeletal Diseases In The United States (BMUS).; 2014.

8. Branney J, Newell D. Back Pain And Associated Healthcare Seeking Behaviour In Nurses: A Survey. Clin Chiropr 2009; 12: 130-43.
9. Icagasioglu A, Yumusakhuylu Y, Ketenci A, Toraman NF, Karatas GK, Kuru O, et al. Burden Of Chronic Low Back Pain In The Turkish Population. Turkish Journal Of Physical Medicine And Rehabilitation 2015; 61: 58-65.

10. Work-Related H And SE Self-Reported, illness And Workplace Injuries in 2013/2015 R From The Http://Www. Hse. Gov. Uk/ Statistics/Lfs/Index. Ht. Occupationbelağrısı.

11. Shieh SH, Sung FC, Su CH, Tsai Y, Hsieh VC. Increased Low Back Pain Risk in Nurses With High Workload For Patient Care: A Questionnaire Survey. Taiwan J Obstet Gynecol 2016; 55: 525-9.

12. Arasan $F$, Gün $K$, Terzibaşıoğlu AM, Sarıdoğan M. Bir Üniversite Hastanesinde Çalışan Hemşirelerde Bel Ağrısı Görülme Sıklığının Belirlenmesi. Cerrahpaşa Tıp Dergisi 2009; 40.

13. Punnett L, Wegman DH. Work-Related Musculoskeletal Disorders: The Epidemiologic Evidence And The Debate. J Electromyogr Kinesiol 2004; 14: 13-23.

14. Fairbank, Jeremy CT, Paul B. Pynsent. "The Oswestry disability index." Spine 2000: 25: 2940-53.

15. Fairbank JC, Couper J, Davies JB, O'Brien JP. The Oswestry low back pain disability questionnaire. Physiotherapy 1980; 66: 2713.

16. Yakut $E$, Düger $T$, Oksüz $C$, Yörükan $S$, Ureten $K$, Turan $D$, et al. Validation Of The Turkish Version Of The Oswestry Disability Index For Patients With Low Back Pain. Spine (Phila Pa 1976) 2004; 29: 581-5; discussion 585.

17. Alexopoulos EC, Burdorf A, Kalokerinou A. Risk Factors For Musculoskeletal Disorders Among Nursing Personnel In Greek Hospitals. Int Arch Occup Environ Health 2003; 76: 289-94.

18. Maul I, Läubli T, Klipstein A, Krueger H. Course Of Low Back Pain Among Nurses: A Longitudinal Study Across Eight Years. Occup Environ Med 2003; 60: 497-503.

19. Josephson $M$, Lagerström $M$, Hagberg $M$, Wigaeus Hjelm $E$. Musculoskeletal Symptoms And Job Strain Among Nursing Personnel: A Study Over A Three Year Period. Occup Environ Med 1997; 54: 681-685.

20. Lipscomb J, Trinkoff A, Brady B, Geiger-Brown J. Health Care System Changes And Reported Musculoskeletal Disorders Among Registered Nurses. Am J Public Health 2004; 94: 1431-5.

21. Solak Kabataş $M$, Kocuk $M$, Küçükler Ö. Sağlık Çalışanlarında Bel Ağrısı Görülme Sıklığı Ve Etkileyen Faktörlerin İncelenmesi. Füsağbiltıp Derg 2012; 26: 65-72.

22. Alçelik A, Deniz F, Yeşildal N, Mayda AS, Ayakta B. Aibü Tıp Fakültesi Hastanesinde Görev Yapan Hemşirelerin Sağlık Sorunları Ve Yaşam Alışkanlıklarının Değerlendirilmesi. TSK Koruyucu Hekimlik Bülteni 2005; 4: 55-65.

23. Parlar S. Sağlık Çalışanlarında Göz Ardı Edilen Bir Durum Sağlıklı Çalışma Ortamı, TAF Preventive Medicine Bulletin 2008; 6: 54754.

24. Çil Akıncı A, Dereli E, Sert H. Kırklareli'nde Çalışan Hemşirelerde Bel Ağrısı Ve Bel Ağrısı Ille Illişkili Faktörler. Acıbadem Üniversitesi Sağlık Bilim Derg 2014; 5: 70-6.

25. June KJ, Cho SH. Low Back Pain And Work-Related Factors Among Nurses In Intensive Care Units. J Clin Nurs 2011; 20: 479-87.

26. Terzi R., Altin F. Hastane Çalişanlarinda Bel Ağrisi Sikliği, Bel Ağrisinin Kronik Yorgunluk Sendromu Ve Mesleki Faktörler İle Iliş̧isi. Agri 2015; 27: 149-54. 
27. Altınel L. Profesyonel Hastane Çalışanlarında Bel Ağrısı Ve Bel Ağrısını Etkileyen Faktörler. Tıp Araştırmaları Derg 2007; 5: 11520.

28. Attar SM. Frequency And Risk Factors Of Musculoskeletal Pain In Nurses At A Tertiary Centre İn Jeddah, Saudi Arabia: A Cross Sectional Study. BMC Res Notes 2014; 7: 61.

29. Cumhur YE, Sa H, Tez S, Do MAN, Ocaktan E. BiR ÜniVersiTe Hastanesi Hemşirelirnide Bel Ağrısı Sıklığı Fonksiyonel Yetersizlik Düzeyi ve Illişkili Etmenler. 2014.

30. Kopec J A, Sayre EC, Esdaile JM. Predictors Of Back Pain in A General Population Cohort. Spine (Phila Pa 1976) 2004; 29: 7077-78. Doi:10.1097/01.BRS.0000103942.81227.7F.

31. Reigo T, Timpka T, Tropp H. The Epidemiology Of Back Pain in Vocational Age Groups. Scand J Prim Health Care 1999; 17: 1721.

32. Cımbız A, Uzgören N, Aras Ö, Öztürk S, Elem, E, Aksoy CC. Kas İskelet Sisteminde Ağrıya Ait Risk Faktörlerinin Lojistik Regresyon Analizi ile Belirlenmesi: Pilot Çalışma. Fizyoter Rehabil 2007; 18: 20-7.

33. Linton SJ, Hellsing AL, Hallden K. A Population-Based Study Of Spinal Pain Among 35-45-Year-Old İndividuals. Prevalence, Sick
Leave, And Health Care Use. Spine (Phila Pa 1976) 1998; 23: 1457-63.

34. Saygılı M. (2008). Hastane Çalışanlarının Çalışma Ortamlarına illişkin Algıları ile iş̧ Doyumu Düzeyleri Arasındaki İlişkinin Değerlendirilmesi.

35. Baydın SŞ, Emel E, Gündağ M, Alataş İ. Gebelik Ve Lomber Disk Herniasyonu, JOPP Derg 2012; 4: 93-6.

36. Smith DR, Mihashi M, Adachi Y, et al. Menstrual Disorders And Their İnfluence On Low Back Pain Among Japanese Nurses. Ind Health 2009; 47: 301-12.

37. Wijnhoven $\mathrm{HAH}$, De Vet HCW, Smit HA, Picavet HSJ. Hormonal And Reproductive Factors Are Associated With Chronic Low Back Pain And Chronic Upper Extremity Pain In Women--The Morgen Study. Spine (Phila Pa 1976) 2006; 31: 1496-502.

38. Tüzün F, Eryavuz M AÜ. Bel ve Bacak Ağrıları. Hareket Sistemi Hastalıkları,Nobel Tıp Kitabevleri, s.245-260, , Ankara, 1997.

39. Karamehmetoğlu ŞS, Karacan I, Çalış M, Koyuncu H. Travma İle Bel Ve/Veya Bacak Ağrısı İlişkisinin Değerlendirilmesi. Turkish Journal of Trauma and Emergency Surgery 1996; 2: 33-7.

40. Çetin N, Şişman TÖ. Bel Ağrıları. İ̧̧ Hast Dergisi Başkent Üniversitesi. 